Annals of International Medical and Dental Research

E-ISSN: 2395-2822 | P-ISSN: 2395-2814

Vol-8, Issue-1 | January-February 2022

DOI: 10.53339/aimdr.2022.8.1.4

Page no- 24-30 | Section- Research Article (Orthopaedics)

\title{
Management of Comminuited Intra/Juxta Articular Fracture of Distal Radius Using Bridging External Fixator
}

\author{
Rakesh Sharma1, Dharam Singh2*, Jagsir Singh ${ }^{3}$, Rajesh Kapila ${ }^{4}$
}

\begin{abstract}
1Professor, Department of Orthopaedics, Goverment Medical College Amritsar, Punjab, India.

Email: drrksharma1927@gmail.com

Orcid ID: 0000-0002-8339-9832

2Associate Professor, Department of Orthopaedics, Goverment Medical College Amritsar, Punjab, India.

Email: dharamsahota18@gmail.com

Orcid ID: 0000-0001-9966-6029

3Junior Resident, Department of Orthopaedics, Govt Medical College Amritsar, Punjab, India.

Email: drjagsir1988@gmail.com

Orcid ID: 0000-0001-8577-5494

4Professor, Department of Orthopaedics, Govt Medical College Amritsar, Punjab, India.

Email: kapila.rajesh@yahoo.com

Orcid ID: 0000-0002-0659-7261
\end{abstract}

*Corresponding author

Received: 28 Ausgust 2021

Revised: 21 October 2021

Accepted: 30 October 2021

Published: 22 December 2021

\begin{abstract}
Background: Distal radius fractures are the third most common osteoporotic fractures and are frequently treated in emergency department. They have a trimodal peak of occurrence and there has been a significant increase in incidence of involvement in elderly females and young males. Management of these fractures comes with lots of treatment options and challenges to provide good functional outcome. This prospective study was done for the management of communited intra/juxta articular fractures of distal end radius using a bridging external fixator on 25 patients. The principle of ligamentotaxis was used for alignment of fracture fragments and wrist spanning external fixator was used to maintain the fracture reduction. Methods: 25 patients of either sex with age group 16 to 80 years were taken from the orthopedic department. After proper primary care, cases were classified using Fernandez classification, and posted for surgery as soon as investigations and fitness were taken. Results: Patients involved in the study were in range of 16 to 78 years with 16 patients having dominant side with road traffic accident as leading cause.Radiological union was seen at an average of 7.3 weeks, 4 patients had superficial pin tract infection, 3 patients had stiffnes and a single case had malunion. Conclusions: Modified clinical scoring system of Green and O'Brien was used to evaluate the overall functional results which showed excellent to good results in $84 \%$ of cases. Hence, properly planned and executed bridging external fixator is an easy, cost-effective and reliable treatment modality through the "Principle of Ligamentotaxis".
\end{abstract}

Keywords:- Distal radius fractures, ligamentotaxis, bridging external fixator.

\section{INTRODUCTION}

Distal radius fractures represent approximately one-sixth of all fractures treated in emergency departments. Distal radius fractures are the third most common fractures in osteoporotic fractures following vertebral and hip fractures. [1] There are three main peaks of distal radial fracture occurrence. First peak is between ages 5 to 14 , the second in males under 50 years of age and the third peak is in females over the age of 40 years. $\left.{ }^{2,3}\right]$ There is a growing incidence of these fractures in all the three groups with significant increase in elderly females and younger adult males. $[2,3,4]$ It is suggested that the two peaks represent two very different injury patterns: 1) An insufficiency fracture in elderly females; 2) Traumatic injury in younger males. [5] 
Annals of International Medical and Dental Research

E-ISSN: 2395-2822 | P-ISSN: 2395-2814

Vol-8, Issue-1 | January-February 2022

DOI: 10.53339/aimdr.2022.8.1.4

Page no- 24-30 | Section- Research Article (Orthopaedics)

Since their description by Colles in 1814, distal radial fractures remain a therapeutic challenge.[6] These often result in permanent deformity, pain, and loss of function. Various surgical interventions are available presently, like percutaneous pinning, intra focal pinning, external fixator and plate fixation. External fixator may be performed in a bridging technique and a non bridging technique. Bridging external fixator allows distraction across the radio carpal joint. The moulding of fracture fragments into alignment by traction force applied across the fracture through the surrounding soft tissue is known as ligamentotaxis. Anderson and $\mathrm{O}$ Neil were first to maintain fracture reduction with an external fixator using the principle of ligamentotaxis. Multiple studies have documented the efficacy of this technique. $[7,8,9]$

Ligamentotaxis is the basic principle used in external fixation. This helps in freeing the impacted fragments and allowing further reduction by joysticking the main fragments. Frequently, this distractor has to be left in-situ in the form of a wrist spanning external fixator till fracture healing as the small fragments are seldom held robustly by those small k-wires. With the improved components \& better understanding of the principles that governs the safe \& effective use, the external fixator has become an indispensable tool in the hands of experienced trauma surgeons. There are few complications with this technique such as stiffness of the fingers, loss of reduction, problems with radial sensory nerve and pin tract infections. $[10,11,12,13,14]$ The main disadvantage of a static external fixator across the wrist may be a permanent loss of wrist motion. $[15,16,17,18]$

\section{MATERIAL AND METHODS}

25 Cases of either sex with intra/juxta-articular fractures of distal radius, admitted in the department of Orthopaedics of Government Medical College, Amritsar were taken for this prospective study. Cases were classified according to Fernandez classification and all non-comminuted fracture of distal radius will be excluded from the study.

Patient was admitted in the Emergency and OPD Department of Guru Nanak Dev Hospital, Amritsar attached to Govt. Medical College, Amritsar. After that patient was examined with respect to the injuries and special attention was given to circulation and neurological status of the limb. Primary treatment in the form of antibiotics, analgesics, immunization against tetanus, intravenous fluid, thorough wound debridement and antiseptic dressing in case of open fracture, and splinting was done. This was followed by radiological examination of the limb in posterior-anterior, lateral and any other special view as indicated. Routine investigations of blood and urine were carried out. As soon as the patient became fit for surgery, he/she operated under appropriate anaesthesia, taking aseptic precautions with proper cleaning and draping. If there was any wound, swab for culture and sensitivity was sent, thorough debridement was done and the wound was properly cleaned. Then the fracture was stabilized by transarticular external fixator device. The implant used for osseous fixation was either Schanz pin or Kirschner wire depending upon the type of fracture. Proximal hold was provided by 2 pins, one $2 \mathrm{~cm}$ proximal to the fracture site and other further proximal to that and distal hold with 2 pins 
Annals of International Medical and Dental Research

E-ISSN: 2395-2822 | P-ISSN: 2395-2814

Vol-8, Issue-1 | January-February 2022

DOI: 10.53339/aimdr.2022.8.1.4

Page no- 24-30 | Section- Research Article (Orthopaedics)

into 2nd and 3rd metacarpal (if necessary, in 4th metacarpal) thus bypassing the fracture site. The proximal and distal holds was connected by connecting roads, distractor and hinges which was used if needed for further adjustment. C-arm fluoroscopy was used for adjustment after reduction. Traction on ligaments and soft tissue around the fracture was applied to reduce the fracture according to the principle of ligamentotaxis and reduction was maintained. Distractor was preferred as these can help in future adjustment. If any additional procedure was required such as bone grafting or skin grafting it was planned either at the same time or later on depending upon the wound condition. Entry points of wires/pins was covered with betadine-soaked gauge for 24-48 hours.

Post-operatively patients were advised active movement of the adjacent joints as early as possible. Wounds were dressed daily. Antibiotics therapy was instituted according to culture sensitivity if needed. The final position and alignment were checked on post-operative $x$-ray. Discharge if any was sent for culture sensitivity every week and antibiotics therapy changed accordingly. This was continued till the wound healed.

Patients were discharged from hospital depending upon the local condition and were called for follow up in Out-patient department every three weeks till the fracture unites. Fixator / distractor was removed once the signs of clinical and radiological union were present. Final function results were evaluated according to modified clinical scoring system of Green and O’Brien.

\section{RESULTS}

In our study 25 cases were included and all of them were followed up for an average period of 6 months. The mean age of the study population was 38.2 years (range 16 years to 78 years), 16 (64\%) were males and 9 (36\%) were females. The right wrist was involved in 56\% (14 cases) and the left in $44 \%$ (11) of our cases. The dominant side was involved in 16 patients. Road traffic accident was the leading cause of injury in 14 patients, second major cause of injury fall in total of 11 patients. Most (20) of the cases were done under brachial block, only 5 cases were given general anaesthesia.

Most of our cases were treated with external fixator in mean 3 days of injury (range 1day to 5 days). The average operative time was 42 minutes (range 25-90 minutes). Out of 25 patients, supplementary procedure (augmentation of external fixator with k-wires and bone grafting) was done in 10 patients. Fixator was removed after 6 weeks followed by hot paraffin wax bath and physiotherapy. The follow-up period averaged 6 months. Radiological union was noticed in 6-10 weeks (mean 7.3 weeks). There were 7 cases out of total 25, which had associated other bone injuries due to higher velocity trauma or fall from height. Associated injuries were involving femur (5), tibia (3), humerus (4), ulna (1), patella (1). One case had complex regional pain syndrome which resolved in 2 months with rigorous physical therapy and medication. Four cases (16\%) had superficial pin tract infection which resolved with local wound care and antibiotics. Three cases (12\%) had wrist stiffness. Marked improvement was seen after two weeks of physiotherapy. Malunion was seen in 1 case $(4 \%)$, which was 
Annals of International Medical and Dental Research

E-ISSN: 2395-2822 | P-ISSN: 2395-2814

Vol-8, Issue-1 | January-February 2022

DOI: 10.53339/aimdr.2022.8.1.4

Page no- 24-30 | Section- Research Article (Orthopaedics)

primarily due to inability to correct the dorsal angulation. Loss of reduction was seen in 1 case which was then readjusted and augmented with k-wires.
Modified clinical scoring system of Green and O'Brien was used to evaluate the overall functional results. Excellent to good result was achieved in $84 \%$ of our cases while fair and poor result was achieved in 4 cases (16\%).

\section{DISCUSSION}

\begin{tabular}{|c|c|c|c|}
\hline S.No & Parameter & Result & Comparison \\
\hline 1 & Age & $\begin{array}{l}\text { Mean } 38.28 \\
(16-78)\end{array}$ & 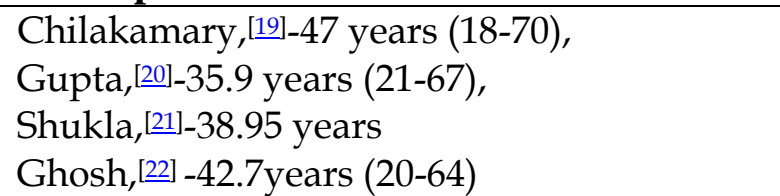 \\
\hline 2 & $\begin{array}{l}\text { Sex } \\
\text {-Male } \\
\text {-Female }\end{array}$ & $\begin{array}{l}16(64 \%) \\
9(36 \%)\end{array}$ & $\begin{array}{l}\text { Gupta,[20]-M:F 61\%:39\%, } \\
\text { Anvekar,[23] -M:F 55\%:45\%, } \\
\text { Chilakamary,[19]-M:F 57.69\%:42.3\%. }\end{array}$ \\
\hline 3 & $\begin{array}{l}\text { Mode of injury } \\
\text {-RSA } \\
\text {-Fall (D) } \\
\text {-Fall (H) }\end{array}$ & $\begin{array}{l}14(56 \%) \\
9(36 \%) \\
2(8 \%)\end{array}$ & $\begin{array}{l}\text { Chilakamary,[19]- RTA } 61.53 \% \text {, fall } 34.61 \% \text {. } \\
\text { Chaturvedi,[24]-RTA } 63.3 \% \text {, fall(D) } 23.3 \% \text {, } \\
\text { fall(H) } 16.66 \% \text {. }\end{array}$ \\
\hline 4 & $\begin{array}{l}\text { Side } \\
\text {-Right } \\
\text {-Left }\end{array}$ & $\begin{array}{l}14(56 \%) \\
11(44 \%)\end{array}$ & $\begin{array}{l}\text { Maruthi,[25]- Right } 56.67 \% \text { and left side } \\
73.33 \% \text {, } \\
\text { Yalavarthi- Right } 58 \% \text {, left } 42 \% \text {. }\end{array}$ \\
\hline 5 & 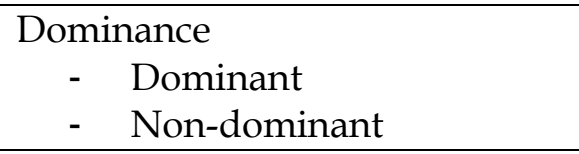 & $\begin{array}{l}16(64 \%) \\
9(36 \%)\end{array}$ & $\begin{array}{l}\text { Gupta, }[20]-65 \% \text { dominant hand, Anvekar }{ }^{23}- \\
60 \% \text { dominant hand } \\
\text { Alam- dominant hand } 64 \%\end{array}$ \\
\hline 6 & $\begin{array}{l}\text { Associated injuries } \\
\text { - } \text { Femur } \\
\text { - } \text { Tibia } \\
\text { - } \text { Humerus } \\
\text { - Ulna } \\
\text { - } \text { Patella } \\
\end{array}$ & $\begin{array}{l}7(28 \%) \\
5 \\
3 \\
4 \\
1 \\
1\end{array}$ & $\begin{array}{l}\text { Anvekar, }[23] \text { - Associated fractures }(7 / 40) \\
\text { Femur }(1) \\
\text { Ulna (1) } \\
\text { Clavicle (3) } \\
\text { Tibia (2). }\end{array}$ \\
\hline 7 & Interval $b / w$ injury and surgery & $\begin{array}{l}\text { Mean } 3.04 \text { day } \\
\text { (1-5 day) }\end{array}$ & $\begin{array}{l}\text { Gupta, }[20] \text {-mean time } 3.5 \text { day }(1-7) \\
\text { Ghosh,[22]-mean } 3.4 \text { days (1-6 ) Alam - } \\
\text { average } 3 \text { day (1-5) Chilakamary- (4 hrs- } 3 \\
\text { days) }\end{array}$ \\
\hline 8 & \begin{tabular}{cc}
\multicolumn{2}{l}{ Supplementary procedure } \\
$-\quad$ & k-wire fixation \\
- & Bone grafting \\
\end{tabular} & $\begin{array}{l}8(32 \%) \\
2(8 \%) \\
\end{array}$ & $\begin{array}{l}\text { Chilakamary, }{ }^{[19]} \text {-Augmentation with K-wire } \\
\text { in } 11 / 25 \text { patients. }\end{array}$ \\
\hline 9 & Time of union & $\begin{array}{l}\text { Mean } 7.3 \text { week } \\
\text { (6-10 week) }\end{array}$ & $\begin{array}{l}\text { Gupta,[20]- } 7.4 \text { weeks (5-11 week) Anvekar }{ }^{23} \text { - } \\
\text { 6-8 weeks } \\
\text { Chilakamary, }{ }^{[19]-7.2 ~ w e e k ~(6-8 ~ w e e k s) ~}\end{array}$ \\
\hline 10 & $\begin{array}{l}\text { Final score ( modified o'brien } \\
\text { and green ) }\end{array}$ & $9(36 \%)$ & $\begin{array}{l}\text { Chaturvedi,[24]_ } \text { Excellent } 26.66 \% \text {, Good } \\
46.66 \% \text {, Fair } 20.00 \% \text {, Poor } 6.66 \%\end{array}$ \\
\hline
\end{tabular}

Copyright: (The author(s), published in Annals of International Medical and Dental Research, Vol-8, Issue-1. This is an open access article under the Attribution-Non Commercial 2.0 Generic (CC BY-NC 2.0) license. (https://creativecommons.org/licenses/by-nc/2.0/) 
Annals of International Medical and Dental Research E-ISSN: 2395-2822 | P-ISSN: 2395-2814 Vol-8, Issue-1 | January-February 2022 DOI: $10.53339 /$ aimdr.2022.8.1.4 Page no- 24-30 | Section- Research Article (Orthopaedics)

\begin{tabular}{|c|c|c|c|}
\hline & $\begin{array}{ll}\text { - } & \text { Excellent } \\
\text { - } & \text { Good } \\
\text { - } & \text { Fair } \\
\text { - } & \text { Poor }\end{array}$ & $\begin{array}{l}12(48 \%) \\
2(8 \%) \\
2(8 \%)\end{array}$ & $\begin{array}{l}\text { Maruthi,[25]- Excellent 30.2\%, Good } 46.66 \% \text {, } \\
\text { Fair } 16.66 \% \text {, Poor } 6.66 \% \\
\text { Jenkins- } 93 \% \text { excellent and good result. }\end{array}$ \\
\hline 11 & $\begin{aligned} & \text { Complication } \\
& \text { - } \text { Pin track } \\
& \text { - } \text { Finger stiffness } \\
& \text { - } \text { Loss of reduction } \\
& \text { - } \text { Malunion } \\
& \text { - } \text { RSD }\end{aligned}$ & $\begin{array}{l}7(28 \%) \\
4(16 \%) \\
3(12 \%) \\
1(4 \%) \\
1(4 \%) \\
1(4 \%)\end{array}$ & $\begin{array}{l}\text { Chilakamary,[19]- } 11.53 \% \text { wrist stiffness and } \\
\text { 7.09\% malunion. } \\
\text { Maruthi,[25]- } 3.33 \% \text { pin track infection, } 16.6 \% \\
\text { malunion, } \\
\text { 3.33\% stiffness and } 6.66 \% \text { RDS. } \\
\text { Yalavarthi- Pin track infection } 36 \% \text {, Pin } \\
\text { loosening } 80 \%, \text { Malunion } 4 \% \text {, } \\
\text { Anvekar,[23] - } 15 \% \text { complications } \\
\text { Gupta,[20]-31\% superficial pin track infection. }\end{array}$ \\
\hline
\end{tabular}

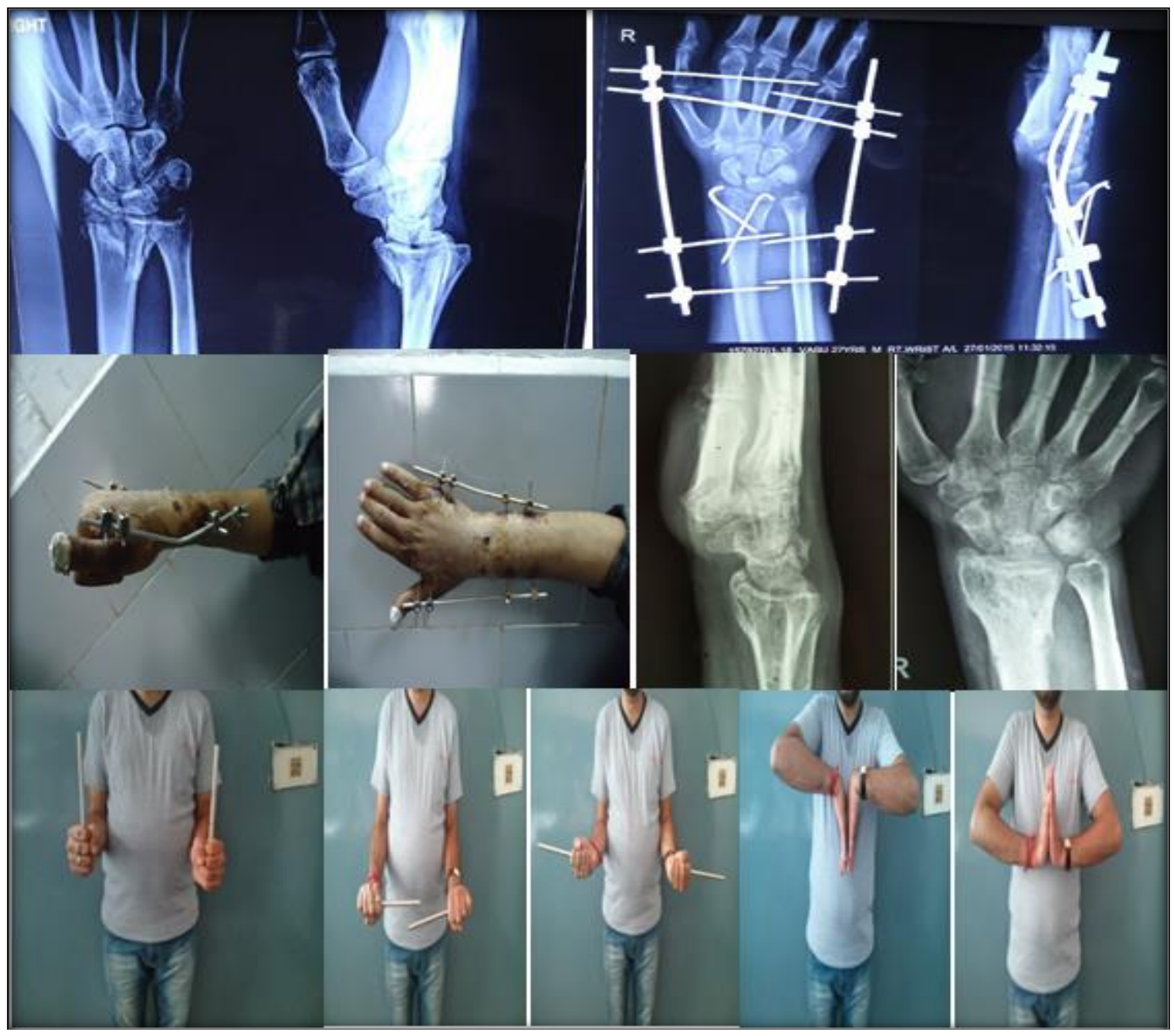

Figure 1: Showing pre-operative and post-operative x-ray (row 1), x-ray of union and fixator insitu (row 2) and Range of motion on final follow up at 6 months (row 3). 
Annals of International Medical and Dental Research

E-ISSN: 2395-2822 | P-ISSN: 2395-2814

Vol-8, Issue-1 | January-February 2022

DOI: 10.53339/aimdr.2022.8.1.4

Page no- 24-30 | Section- Research Article (Orthopaedics)

\section{CONCLUSIONS}

The use of external fixator is an effective method of treating unstable extra-articular and complex intra-articular fractures of the distal end of radius. The external fixator is a simple device which is easy and safe to use even under regional anaesthesia with the distinct advantage of superior mechanical efficiency and capacity of fracture adjustment during healing period and unimpeded access to wounds in cases of open fractures. The shorter period of surgery, less tourniquet time and

\section{REFERENCES}

1. Melton LJ 3rd, Chrischilles EA, Cooper C, Lane AW, Riggs BL. Perspective. How many women have osteoporosis? J Bone Miner Res. 1992;7(9):1005-10. doi: 10.1002/jbmr.5650070902.

2. Chilakamary VK, Lakkireddy M, Koppolu KK, Rapur S. Osteosynthesis in Distal Radius Fractures with Conventional Bridging External Fixator; Tips and Tricks for Getting Them Right. J Clin Diagn Res. 2016;10(1):RC05-RC8. doi:10.7860/JCDR/2016/16696.7048

3. Solgaard S, Petersen VS. Epidemiology of distal radius fractures. Acta Orthop Scand. 1985;56(5):3913. doi: 10.3109/17453678508994354.

4. Mensforth RP, Latimer BM. Hamann-Todd Collection aging studies: osteoporosis fracture syndrome. Am J Phys Anthropol. 1989;80(4):461-79. doi: 10.1002/ajpa.1330800406.

5. Nguyen TV, Center JR, Sambrook PN, Eisman JA. Risk factors for proximal humerus, forearm, and wrist fractures in elderly men and women: the Dubbo Osteoporosis Epidemiology Study. Am J Epidemiol. 2001;153(6):587-95. doi: 10.1093/aje/153.6.587.

6. Colles A. On the fracture of the carpal extremity of the radius. Edinb Med Surg J. 1814;10:181. Clin Orthop Relat Res. 2006;445:5-7. doi: 10.1097/01.BLO.000020589575491.a8. minimal exposure are its distinct advantage over plate fixation. It can be performed in emergency with minimum instrumentation and expertise. Complications like pin tract infection are rare. Wrist and finger stiffness can be avoided by appropriate physiotherapy. Hence, properly planned and executed bridging external fixator is an easy, costeffective and reliable treatment modality in treating comminuted intra-articular and unstable extra-articular distal end of Radius fractures by the "Principle of Ligamentotaxis".

7. Edwards GS Jr. Intra-articular fractures of the distal part of the radius treated with the small AO external fixator. J Bone Joint Surg Am. 1991;73(8):1241-50.

8. Fernandez DL, Geissler WB. Treatment of displaced articular fractures of the radius. J Hand Surg Am. 1991;16(3):375-84. doi: 10.1016/0363-5023(91)90001r.

9. Gogna P, Selhi HS, Singla R, Devgan A, Magu NK, Mahindra $P$, et al. Dorsally comminuted fractures of the distal end of the radius: osteosynthesis with volar fixed angle locking plates. ISRN Orthop. 2013;2013:131757. doi: 10.1155/2013/131757.

10. Egol K, Walsh M, Tejwani N, McLaurin T, Wynn C, Paksima N. Bridging external fixation and supplementary Kirschner-wire fixation versus volar locked plating for unstable fractures of the distal radius: a randomised, prospective trial. J Bone Joint Surg Br. 2008;90(9):1214-21. doi: 10.1302/0301620X.90B9.20521.

11. Ahlborg HG, Josefsson PO. Pin-tract complications in external fixation of fractures of the distal radius. Acta Orthop Scand. 1999;70(2):116-8. doi: $10.3109 / 17453679909011246$.

12. Botte MJ, Davis JL, Rose BA, von Schroeder HP, Gellman H, Zinberg EM, et al. Complications of smooth pin fixation of fractures and dislocations in the hand and wrist. Clin Orthop Relat Res. 1992;(276):194-201. 
Annals of International Medical and Dental Research

E-ISSN: 2395-2822 | P-ISSN: 2395-2814

Vol-8, Issue-1 | January-February 2022

DOI: 10.53339/aimdr.2022.8.1.4

Page no- 24-30 | Section- Research Article (Orthopaedics)

13. Glowacki KA, Weiss AP, Akelman E. Distal radius fractures: concepts and complications. Orthopedics. 1996;19(7):601-8.

14. Egol KA, Walsh M, Romo-Cardoso S, Dorsky S, Paksima N. Distal radial fractures in the elderly: operative compared with nonoperative treatment. J Bone Joint Surg Am. 2010;92(9):1851-7. doi: 10.2106/JBJS.I.00968.

15. Grewal R, Perey B, Wilmink M, Stothers K. A randomized prospective study on the treatment of intra-articular distal radius fractures: open reduction and internal fixation with dorsal plating versus mini open reduction, percutaneous fixation, and external fixation. J Hand Surg Am. 2005;30(4):764-72. doi: 10.1016/j.jhsa.2005.04.019.

16. Chilakamary VK, Lakkireddy M, Koppolu KK, Rapur S. Osteosynthesis in Distal Radius Fractures with Conventional Bridging External Fixator; Tips and Tricks for Getting Them Right. J Clin Diagn Res. 2016;10(1):RC05-8. doi: 10.7860/JCDR/2016/16696.7048.

17. Gupta U, Chaudhary S, Khan A, Pathania VP. Treatment of intra-articular distal retinus fractures by a combined dynamic and static jess mini external fixator techniqueJ. Evol Med Dent. 2014; 3(21):588693.

18. Shukla R, Jain RK, Sharma NK, Kumar R. External fixation versus volar locking plate for displaced intra-articular distal radius fractures: a prospective randomized comparative study of the functional outcomes. J Orthop Traumatol. 2014;15(4):265-70. doi: 10.1007/s10195-014-0317-8.
19. Ghosh S, Dutta S, Chaudhuri A, Datta S, Roy DS, Singh AK. Comparative analysis of external and internal fixation in lower radial articular fractures. Med J DY Patil Vidyapeeth. 2014;7(5):596.

20. Anvekar PM, Nimbargi SS, Srinath SR, Nelivigi AS. Treatment of intra-articular fracture of distal radius with static external fixators-ligamentotaxis-a prospective study. JEMDS. 2013;2(32):6026-38.

21. Chaturvedi B, Ali SKI, Krisna S. Modality of treatment of the distal end radius fracture. Int J Sci Res. 2014; 4(11):2250-53.

22. Maruthi CV. Management of fracture of distal radius by external fixator using the principle of ligamentotaxis a prospective study. Indian J Orthop Surg. 2016;2(1):19-26.

23. Yalavarthi RK, Vishal A. Outcome of management of distal radius fractures by ligamentotaxis. J Dent Med Sci .2015;1(14):33-7.

24. Alam W, Shah FA, Qureshi KM, Rehman SU, Hussain S, Imran M. Intra-articular fractures of distal radius. Professional Med J. 2014;21(04):649-53.

25. Jenkins NH, Jones DG, Johnson SR, Mintowt-Czyz WJ. External fixation of Colles' fractures. An anatomical study. J Bone Joint Surg Br. 1987;69(2):207-11. doi: 10.1302/0301620X.69B2.3818750.

Source of Support: Nil, Conflict of Interest: None declared 